\title{
Front Matter: Volume 10500
}

, "Front Matter: Volume 10500," Proc. SPIE 10500, Single Molecule Spectroscopy and Superresolution Imaging XI, 1050001 (7 May 2018); doi: $10.1117 / 12.2323025$

SPIE. Event: SPIE BiOS, 2018, San Francisco, California, United States 


\title{
PROGRESS IN BIOMEDICAL OPTICS AND IMAGING

\section{Single Molecule Spectroscopy and Superresolution Imaging XI}

\author{
Jörg Enderlein \\ Ingo Gregor \\ Zygmunt Karol Gryczynski \\ Rainer Erdmann \\ Felix Koberling \\ Editors
}

27-28 January 2018

San Francisco, California, United States

Sponsored by

SPIE

Cosponsored by

PicoQuant Photonics (United States)

Published by

SPIE 
The papers in this volume were part of the technical conference cited on the cover and title page. Papers were selected and subject to review by the editors and conference program committee. Some conference presentations may not be available for publication. Additional papers and presentation recordings may be available online in the SPIE Digital Library at SPIEDigitalLibrary.org.

The papers reflect the work and thoughts of the authors and are published herein as submitted. The publisher is not responsible for the validity of the information or for any outcomes resulting from reliance thereon.

Please use the following format to cite material from these proceedings:

Author(s), "Title of Paper," in Single Molecule Spectroscopy and Superresolution Imaging XI, edited by Jörg Enderlein, Ingo Gregor, Zygmunt Karol Gryczynski, Rainer Erdmann, Felix Koberling, Proceedings of SPIE Vol. 10500 (SPIE, Bellingham, WA, 2018) Seven-digit Article CID Number.

ISSN: 1605-7422

ISSN: $2410-9045$ (electronic)

ISBN: 9781510614857

ISBN: 9781510614864 (electronic)

Published by

SPIE

P.O. Box 10, Bellingham, Washington 98227-0010 USA

Telephone +1 3606763290 (Pacific Time) · Fax +1 3606471445

SPIE.org

Copyright @ 2018 , Society of Photo-Optical Instrumentation Engineers.

Copying of material in this book for internal or personal use, or for the internal or personal use of specific clients, beyond the fair use provisions granted by the U.S. Copyright Law is authorized by SPIE subject to payment of copying fees. The Transactional Reporting Service base fee for this volume is $\$ 18.00$ per article (or portion thereof), which should be paid directly to the Copyright Clearance Center (CCC), 222 Rosewood Drive, Danvers, MA 01923. Payment may also be made electronically through CCC Online at copyright.com. Other copying for republication, resale, advertising or promotion, or any form of systematic or multiple reproduction of any material in this book is prohibited except with permission in writing from the publisher. The CCC fee code is 1605$7422 / 18 / \$ 18.00$.

Printed in the United States of America.

Publication of record for individual papers is online in the SPIE Digital Library.

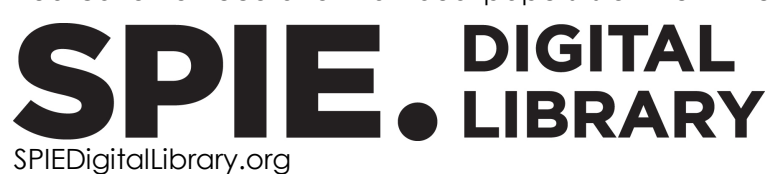

SPIEDigitalLibrary.org

Paper Numbering: Proceedings of SPIE follow an e-First publication model. A unique citation identifier (CID) number is assigned to each article at the time of publication. Utilization of CIDs allows articles to be fully citable as soon as they are published online, and connects the same identifier to all online and print versions of the publication. SPIE uses a seven-digit CID article numbering system structured as follows:

- The first five digits correspond to the SPIE volume number.

- The last two digits indicate publication order within the volume using a Base 36 numbering system employing both numerals and letters. These two-number sets start with $00,01,02,03$, $04,05,06,07,08,09,0 A, 0 B \ldots$. 0Z, followed by 10-1Z, 20-2Z, etc. The CID Number appears on each page of the manuscript. 


\title{
Contents
}

\author{
$\checkmark \quad$ Authors \\ vii Conference Committee
}

FLIM, FCS AND FRET I

1050002 Photon spectroscopy by picoseconds differential Geiger-mode Si photomultiplier [10500-1]

FLIM, FCS AND FRET II

1050007 Analyzing conformational changes in single FRET-labeled $A_{1}$ parts of archaeal $A_{1} A_{0}$-ATP synthase [10500-6]

NANOSCOPY OR SUPER-RESOLUTION FLUORESCENCE IMAGING I

10500 OB Measuring 3D molecular orientation and rotational mobility using a Tri-spot point spread function [10500-12]

\section{NANOSCOPY OR SUPER-RESOLUTION FLUORESCENCE IMAGING II}

10500 OC A simple and low-cost structured illumination microscopy using a pico-projector [10500-13]

10500 OD Characterization and improvement of highly inclined optical sheet microscopy [10500-14]

10500 OE A robust statistical estimation (ROSE) algorithm jointly recovers the 3D location and intensity of single molecules accurately and precisely [10500-15]

\section{BIOLOGICAL APPLICATIONS OF SM SPECTROSCOPY AND IMAGING}

10500 OL Interferometric scattering (iSCAT) microscopy: studies of biological membrane dynamics [10500-22]

10500 OM Tilted light sheet microscopy with 3D point spread functions for single-molecule superresolution imaging in mammalian cells (PicoQuant Young Investigator Award ) [10500-23]

10500 ON Identifying and correcting pixel locking errors with the SPIFF algorithm [10500-24] 
NANOSCOPY OR SUPER-RESOLUTION FLUORESCENCE IMAGING IV

$10500 \mathrm{OQ}$ Superresolution fluorescence imaging by pump-probe setup using repetitive stimulated transition process [10500-27]

POSTER SESSION

10500 OS Ultrafast single molecule technique for the study of force dependent kinetics and conformational changes of actin-protein interaction involved in mechanotransduction [10500-29]

10500 OU Diagram method for resolution limit calculation in laser microscopy [10500-31] 


\section{Authors}

Numbers in the index correspond to the last two digits of the seven-digit citation identifier (CID) article numbering system used in Proceedings of SPIE. The first five digits reflect the volume number. Base 36 numbering is employed for the last two digits and indicates the order of articles within the volume. Numbers start with 00, 01, 02, 03, 04, 05, 06, 07, 08, 09, 0A, OB...0Z, followed by 10-1Z, 20-2Z, etc.

Arbore, C., OS

Börsch, Michael, 07

Capitanio, M., OD, OS

Cole, Daniel, OL

Curcio, V., OD

Dake, Fumihiro, $O Q$

Ding, Tianben, $\mathrm{OB}$

Eggeling, Christian, OL

Fukutake, Naoki, OQ, OU

Galiani, Silvia, OL

Gardini, L., OD

Grüber, Gerhard, 07

Gustavsson, Anna-Karin, OM

Hayashi, Seri, $0 Q$

Hernandez, Keegan, 02

Kukura, Philipp, OL

Lagerholm, B. Christoffer, OL

Lee, Maurice Y., OM

Lew, Matthew D., OB, OE

Lu, Jin, OB

Mazidi, Hesam, OB, OE

Moerner, W. E., OM

Nehorai, Arye, $\mathrm{OE}$

Özgürün, Baturay, OC

Pavone, F. S., OD, OS

Petrov, Petar N., OM

Reina, Francesco, OL

Robinson, J. Paul, 02

Scherer, Norbert F., ON

Sergides, M., OS

Sezgin, Erdinc, OL

Shechtman, Yoav, OM

Shrestha, Dilip, OL

Sielaff, Hendrik, 07

Singh, Dhirendra, 07

Sule, Nishant, $\mathrm{ON}$

Taki, Yusuke, $0 Q$

Vignolini, T., OD

Yamamoto, Masanobu, 02

Yifat, Yuval, ON

Zhang, Oumeng, OB 
Proc. of SPIE Vol. $105001050001-6$

Downloaded From: https://www.spiedigitallibrary.org/conference-proceedings-of-spie on 26 Apr 2023 Terms of Use: https://www.spiedigitallibrary.org/terms-of-use 


\title{
Conference Committee
}

\author{
Symposium Chairs
}

James G. Fujimoto, Massachusetts Institute of Technology

(United States)

R. Rox Anderson, Wellman Center for Photomedicine, Massachusetts

General Hospital (United States) and Harvard Medical School

(United States)

Program Track Chairs

Ammasi Periasamy, University of Virginia (United States)

Daniel L. Farkas, University of Southern California (United States) and SMI (United States)

Conference Chairs

Jörg Enderlein, Georg-August-Universität Göttingen (Germany) Ingo Gregor, Georg-August-Universität Göttingen (Germany)

Zygmunt Karol Gryczynski, University of North Texas Health Science Center at Fort Worth (United States) and Texas Christian University at Fort Worth (United States)

Rainer Erdmann, PicoQuant GmbH Berlin (Germany)

Felix Koberling, PicoQuant GmbH (Germany)

\section{Conference Program Committee}

Sohail Ahmed, A*STAR Institute of Medical Biology (Singapore)

Michael Börsch, Friedrich-Schiller-Universität Jena (Germany)

Christian Eggeling, University of Oxford (United Kingdom)

Paul M. W. French, Imperial College London (United Kingdom)

Ewa M. Goldys, Macquarie University (Australia)

Johan Hofkens, Katholieke University Leuven (Belgium)

Zhen-Li Huang, Huazhong University of Science and Technology (China)

Thomas R. Huser, Universität Bielefeld (Germany)

Maria Teresa Neves-Petersen, Aalborg University (Portugal)

Markus Sauer, Universität Bielefeld (Germany)

Shimon Weiss, University of California, Los Angeles (United States)

Andong Xia, Institute of Chemistry (China) 
Session Chairs

1 FLIM, FCS and FRET I

Rainer Erdmann, PicoQuant GmbH (Germany)

2 FLIM, FCS and FRET II

Felix Koberling, PicoQuant GmbH (Germany)

3 Nanoscopy or Super-resolution Fluorescence Imaging I

Felix Koberling, PicoQuant GmbH (Germany)

4 Nanoscopy or Super-resolution Fluorescence Imaging II

Zygmunt Karol Gryczynski, University of North Texas Health Science Center at Fort Worth (United States) and Texas Christian University at Fort Worth (United States)

$5 \quad$ Nanoscopy or Super-resolution Fluorescence Imaging III

Zygmunt Karol Gryczynski, University of North Texas Health Science Center at Fort Worth (United States) and Texas Christian University at Fort Worth (United States)

6 Biological Applications of SM Spectroscopy and Imaging Felix Koberling, PicoQuant GmbH (Germany)

$7 \quad$ Nanoscopy or Super-resolution Fluorescence Imaging IV Rainer Erdmann, PicoQuant GmbH (Germany) 